\title{
AS COLOCAÇÕES: FORMA SOCIAL, SISTEMA TECNOLÓGICO, UNIDADE DE RECURSOS NATURAIS
}

\author{
Mauro William Barbosa de Almeida ${ }^{1}$
}

\begin{abstract}
Resumo
0 modo de vida nas colocações florestais é a base do conceito de Reserva Extrativista proposto pelo movimento social dos seringueiros amazônicos na década de 1980. Esse modo de vida formou-se sob o sistema hierárquico e especializado de aviamento, mas está longe de reduzir-se a ele. A colocação é uma organização social e um sistema econômico caracterizado pelo uso múltiplo de territórios florestais por uma rede de casas aparentadas, compartilhando ambientes em comum. 0 sistema das colocações possui o potencial para constitui-se, sob seu reconhecimento institucional como base das reservas extrativistas, no modelo de uma instituição coletiva de uso da floresta que é pouco agressiva para com a natureza e que pode proporcionar uma boa vida a seus habitantes.
\end{abstract}

Palavras-chave: Seringal. Seringueiro. Colocação. Reserva extrativista. Amazonia.

\section{THE COLOCAÇÃO: SOCIAL FORM, TECHNOLOGICAL SYSTEM, UNIT OF NATURAL RESOURCES}

\begin{abstract}
The colocação de seringa, or rubber settlement, sas a way of life is at the basis of the concept of extractive reserve put forward by the social movement of rubber tappers in the 1980s. This way of life grew within the hierarchical and specialized aviamento system, but is far from identical to it. The colocação is both a social organization and

\footnotetext{
${ }^{1}$ Professor do Departamento de Antropologia Social da Universidade Estadual de Campinas. Brasil. mwba@uol.com.br
} 
an economic system characterized by the multiple use of forest territories by a network of related casas, sharing a set of core resources in common. The colocações system has the potential of becoming, under its institutional role as the unit of extractive reserves, a model for a collective institution of forest use with low aggressiveness towards the nature and a promise of a good life for its inhabitants.

Keywords: Seringal. Rubber tappers. Colocação. Extractive reserve. Amazonia.

\section{APRESENTAÇÃo}

Este artigo surgiu de uma palestra realizada em janeiro de 1988 em Rio Branco, Acre, cujo texto foi reapresentado no Centro de Estudos Indígenas (UNESP-Araraquara) em 1990. ${ }^{2}$ Para sua republicação depois de duas decàdas, com revisões e comentários, há duas razões. A primeira é que o texto, que circulou muito pouco na publicação do Centro de Estudos Indígenas de Araraquara (Revista Indígena, ano 7, n. 54, 1990), contém a primeira descrição, que eu saiba, do sistema de colocações dos antigos seringais do alto Juruá, e por isso conserva alguma pertinência como um modelo do modo de vida de seringueiros, visto do ponto de vista do uso da floresta pelos moradores, e não do ponto de vista do sistema dos barracões. Uma segunda razão é que o texto abaixo, embora apoiado na pesquisa de campo feita em seringais do alto Juruá, utilizou frequentemente números aproximados como médias de áreas e tempos, de pessoas e de dias, para caracterizar uma colocação de modo um tanto idealizado: a presente publicação acrescenta algumas especificações a essa visão da colocação como um modelo ou tipo ideal. ${ }^{3}$ E há uma terceira razão para publicar uma versão comentada de um artigo com mais de vinte anos de idade. Um pressuposto do programa de implantar Reservas Extrativistas, formulado por seringueiros e não por planejadores, era o objetivo de conservar e melhorar o sistema de colocações, abolindo porém 0 sistema do barracão. Esse programa teve sua implementação iniciada no Alto

\footnotetext{
${ }^{2}$ Nesta apresentação, escrita em 2012, explico porque escolhi, para homenagear a memória de Valentin Wawzyniak, a publicação comentada e revisada de um texto originalmente escrito em 1988.

N.E.: Foi conservado o estilo proposto pelo autor para diferenciar os trechos da versão de 1988 (publicada em 1990) e os introduzidos na versão de 2012.

${ }^{3}$ Os dados do texto original se apoiavam nos Censos Demográficos e Agropecuários de 1970, 1980 e 1985, e na pesquisa de campo realizada de setembro de 1982 a novembro de 1983, e de julho setembro de 1987, no alto Juruá e particularmente no alto rio Tejo (ALMEIDA, 1993).
} 
Juruá com a formação da Associação dos Seringueiros e Agricultores da Bacia do Rio Tejo já em 1989, com o início de um sistema de cantinas, transporte e financiamento independente gerido pela Associação e pelo Conselho Nacional dos Seringueiros (com recursos do BNDES) e, após um ano de violenta oposição dos patrões, com o decreto de criação da Reserva Extrativista do Alto Juruá em 16 de janeiro de $1990 .^{4}$

Mas a construção do ideal de um modo de vida de colocações florestais sem a exploração patronal contido nessa palestra enfrentou as injunções inevitáveis da história real: mais uma vez, aprendemos com a prática que a história se faz por caminhos imprevisíveis e não como queremos. A palestra original foi realizada em janeiro de 1988, na sede da Fundação Cultural (hoje Fundação Elias Mansur), em Rio Branco. Era parte de um simpósio organizado pelo Instituto de Estudos Amazônicos, dirigido por Mary Allegretti, e ocorria simultaneamente com uma cerimônia em que o Governo do Estado do Acre anunciava na presença de representantes de bancos multilaterais a criação do Assentamento Extrativista de São Luís do Remanso. Esse assentamento extrativista não era uma demanda social, e tinha a finalidade indisfarçada de responder às críticas internacionais aos impactos desastrosos da BR-364 assinalados em Rondônia e que eram antecipados no Acre. Ao mesmo tempo, porém, ocorria uma reunião a portas fechadas do Conselho Nacional dos Seringueiros - com a presença de Chico Mendes, Jaime Araújo, Osmarino Amâncio, Raimundo de Barros e outros líderes sindicais florestais - para planejar atividades para 1988 utilizando recursos que acabavam de ser obtidos da CEBEMO (com a intermediação do CEDI de São Paulo) para um programa de implantação das Reservas Extrativistas na Amazônia. Estas eram demandas dos seringueiros em ex-seringais invadidos por fazendeiros como no vale do Purus, ou de seringais tradicionais ativos que caminhavam para o caminho da exploração predatória de madeira como no vale do Juruá. Uma decisão importante desta reunião foi a indicação e aprovação de Antonio Batista de Macedo como coordenador de uma seção regional do Conselho no Alto Juruá.

$\mathrm{Na}$ palestra, eu me dirigia tanto aos participantes do Simpósio que eram pesquisadores e críticos do modelo vigente de ocupação agropecuária da Amazônia, como Marianne Schmink, Stephen Schwartzman e Susanna Hecht; como aos líderes seringueiros e aos intelectuais e militantes acreanos como Antonio Alves e Terri Vale do Aquino. A tese apresentada aos observadores externos

${ }^{4}$ Para mais detalhes, veja-se Almeida (2004). 
era simples: enquanto até então sociólogos e historiadores de inclinação marxista ou desenvolvimentista viam o fim dos seringais como sinônimo do fim dos próprios seringueiros e da vida na floresta, o movimento dos seringueiros defendia era 0 fim dos seringais, com a conservação do modo de vida associado às colocações. A questão colocada aos líderes seringueiros era: como poderão os seringueiros substituir o sistema patronal e reorganizar coletivamente a vida na floresta ao manter o sistema das colocações? As duas questões continuam a exigir respostas, agora com apoio em duas décadas em que a ideia de Reservas Extrativistas difundiu-se em dezenas de variantes em todo o país.]

\section{ColocaÇões ${ }^{5}$}

De acordo com dados do Censo de 1980, os seringueiros constituíam metade da força de trabalho rural acreana, gerando $33 \%$ do valor da produção rural, e utilizando 50\% das terras do Estado. ${ }^{6}$ Utilizando os dados do Censo Agropecuário, é possível estimar entre 13.000 e 18.000 o número de colocações de seringueiros, 0 que permite ainda estimar que essa economia empregaria cerca de 38.000 pessoas, sustentado cerca de 100.000 moradores da floresta. 0 objetivo desta exposição é

\footnotetext{
${ }^{5}$ A partir daqui, o texto é o da palestra de 1988, na versão publicada em 1990 em Terra Indígena. Como foi dito acima, as notas de rodapé e os anexos são de 2012, bem como os trechos entre colchetes no texto principal e a Bibliografia.

6 Em 1988, meu objetivo era mostrar que ainda na década de 1970-1980 a economia florestal extrativista e mais especificamente a coleta de látex e fabricação da borracha era a principal ocupação e fonte de renda da população não-urbana. Os dados do censo apoiavam a afirmação principal de minha tese de 1993, a saber, que essa atividade se apoiava em unidades familiares de produção, as colocações que descrevi como casas camponesas. Os dados invocados nestes parágrafos iniciais apoiavam-se nos Censos Agropecuários de 1970 e 1980, mas não preparei tabelas para a exposição oral. Faço isso agora, utilizando apenas os dados do Censo de 1980, embora isso dê origem a algumas diferenças face aos números indicados no texto. Em 1980, a mão-de-obra economicamente ativa ocupada com a extração de borracha constituía 46\% da força de trabalho rural, contra $42 \%$ da mão-de-obra rural empregada na Agricultura, Silvicultura e Pecuária (ANEXO 1, Tabela 1) (IBGE 1983a). Os dados percentuais para valor e área ao que parece foram trocados no texto: o valor da produção extrativista é de 49\% ( $\approx$ $50 \%$ ) em relação ao valor da produção rural (ANEXO 1, Tabela 2) (IBGE, 1983b), e a área ocupada pela atividade extrativista é 33\% da área do Estado para 1980 (ANEX0 1, Tabela 3) (IBGE 2006a). A Tabela 3 permite ainda ver que 1980 é o ano em que a atividade extrativista atinge um máximo (sob o efeito de políticas de estímulo), começando a declinar a partir daí (sob o efeito do fim dessas políticas).
} 
contribuir para a discussão dos direitos dessa população como integrantes do país e do Acre?

Falar sobre o uso dos recursos naturais por seringueiros apresenta uma dificuldade inicial. Os seringueiros são chamados de trabalhadores extrativistas. 0 extrativismo é associado automaticamente em nossos ouvidos ao sistema dos seringais e dos barracões. Virou sinônimo, assim, de atraso técnico, de dependência, de degradação ambiental, de escravidão por dívidas, de privação de cidadania e de ideologia de terror. ${ }^{8}$

Defendo aqui a tese de que essa síndrome do extrativismo [tecnicamente] estagnado, [socialmente] dependente e [ecologicamente] predatório deriva das relações sociais de distribuição e de poder nos seringais, e não do extrativismo enquanto modo de uso de recursos naturais e enquanto forma de vida [na floresta]. Com o colapso do mercado mundial para a borracha, [já em 1920] a máquina extrativo-exportadora dos barracões tornou-se obsoleta. Com isso, os seringueiros

\footnotetext{
${ }^{7}$ Os dados de "mão-de-obra economicamente ativa" dão para um total de 23.813 trabalhadores ocupados na extração de borracha em 1980 (ANEXO 1, Tabela 1). Quanto aos estabelecimentos, os dados do Censo indicam 13.360 "estabelecimentos" dedicados à extração vegetal (IBGE 1983a, Tabela 6, p. 10), ou ainda 12.213 se retirarmos desse número os "proprietários". 0 total de 13.360 leva a uma população dependente do extrativismo de 80.160pessoas (com um tamanho de 6 pessoas por unidade doméstica baseado em meu estudo de caso (ALMEIDA, 1993). Ver Anexo 1, Tabela 4 e IBGE 1983, Tabela 4, p. 8. Os dados de área, produção e pessoal ocupado apóiam a interpretação do "estabelecimento" extrativista como aquilo que chamamos aqui de colocação (IBGE 1980a, XXII).

${ }^{8}$ Essa longa lista apoiava-se na literatura existente até 1985 aproximadamente, e também na minha experiência de 1985 a 1980. Sobre o lado "atraso técnico", tinha em mente Celso Furtado e Boeke que pensavam o atraso técnico como parte de uma economia "dualista" (metade economia de subsistência, metade economia exportadora (BOEKE, 1953; FURTAD0, 1959). A análise do extrativismo como "dependência" estava na obra de Stephen Bunker (1985) e como exemplo da "ideologia de terror" associada à escravidão por dívidas, veja-se Michael Taussig (1993), além de José de Souza Martins (1994). Trabalhos de economistas e historiadores formados na Universidade Federal do Acre compartilhavam essa visão, para a qual o melhor destino possível para os seringueiros era a desaparição rápida, e sua conversão em trabalhadores assalariados (DUARTE, 1987). Os seringueiros não eram assunto teórico até meados da década de 1980, com poucas exceções, como as teses de Teixeira Correa sobre seringueiros de Rondônia (TEIXEIRA, 1980), de Mary Allegretti sobre movimentos sociais de seringueiros de Tarauacá (ALLEGRETTI, 1979, 1989, 1990), e a dissertação de Terri Vale de Aquino (1977) sobre os seringueiros "caboclos" do mesmo vale do Tarauacá. Obras anteriores sobre seringais não se apoiaram em pesquisa feita diretamente entre seringueiros, observação que se aplica mesmo ao diário de viagem de Euclides da Cunha de 1905.
} 
tiveram que desenvolver, a partir de sua experiência camponesa [nordestina], mas, sobretudo aprendendo tecnologias indígenas, um modo de vida florestal, que dependesse ao mínimo de bens importados. Foi a origem do atual sistema de colocações. ${ }^{9}$

Hoje, enquanto os seringais estão obsoletos, as colocações são o embrião de um modo de adaptação humana à floresta tropical que é social, ecológica e economicamente promissor. Coloca-se para os trabalhadores da mata, portanto, uma tarefa revolucionária e difícil: destruir o sistema anacrônico dos seringais, e desenvolver o sistema das colocações. Abolir as relações sociais de patronagem, elevando a um novo patamar o manejo agroextrativista auto-sustentado criado pelos seringueiros. ${ }^{10}$

Esse programa começou a se delinear ao final dos anos 1970. Ele é uma revolução teórica e um reajuste de contas de nós, acreanos, com um passado onde o seringal se associa a sentimentos de identidade e de culpa. ${ }^{11}$ Meu antigo colega do

${ }^{9}$ Essa afirmação, que ainda soa estranha, é o que procuro demonstrar em minha tese de
doutorado que fiz ao longo da década de 1980 e defendi em fevereiro de 1993 na Inglaterra
(ALMEIDA, 1993). Nela, o argumento histórico ocupa os quatro primeiros capítulos, enquanto
o argumento de etnografia econômica ocupa os capítulos restantes. Ela coincide com a posição
da então jovem historiadora Barbara Weinstein em livro publicado em 1982 e que confirmou e
influenciou minha análise. A tese de que os seringueiros tornaram-se camponeses foi afirmada
por Baxk a partir do caso dos seringueiros de Xapuri, com uma diferença crucial: para Baxk
esse processo resultou da saída dos patrões de seringal da floresta no contexto da ocupação
de terras pela pecuária nas décadas de 1970 e 1980 (BAKX, 1986, 1988). Esse campesinato
seria o agente da resistência à desapropriação. No Alto Juruá as estradas ainda não haviam
chegado em 1980, e ainda não há estradas até o alto Tejo; tampouco haviam chegado as
fazendas de sulistas (e havia um único projeto de colonização). Contudo, houve resistência
seringueira desde a década de 1910 até 1980 . Na minha análise, a formação do campesinato
de seringueiros começa com a crise dos seringais na década de 1910. ${ }^{10}$ A posição de otimismo político (refletindo minha atuação como "assessor" do Conselho Nacional dos Seringueiros), e apoiada pela tese da autonomia das colocações face ao sistema de patronagem de seringais (refletindo o ângulo etnográfico de minha pesquisa de campo), era aqui equilibrada pela percepção das dificuldades face ao programa de emancipar o modo de vida florestal. Essas eram dificuldades de "ação coletiva" que discuto no último capítulo de minha tese de 1993, que trata do projeto de Reservas Extrativistas.

${ }^{11}$ Isto é: com Terri Vale de Aquino (1977) e Mary Allegretti (1979, 1989, 1990), com pesquisa junto aos "seringueiros caboclos" Kaxinawá e aos seringueiros do seringal Alagoas em Tarauacá respectivamente. Em ambos os casos, a pesquisa se desdobrou em uma intensa atividade prática em apoio à luta indígena no caso de Terri de Aquino e de apoio à luta dos seringueiros no caso de Mary Allegretti. 
Ginásio Acreano, Terri Vale de Aquino, descobriu que os Caxinauás do rio Jordão, que a etnologia declarara extintos pela frente de expansão extrativista, haviam conseguido sobreviver, dotados de identidade étnica e de vontade de viver como Caxinauá, ao contrário dos que alegam aqueles ignorantes que maliciosamente confundem sobrevivência com "aculturação", para, com o argumento desta, anular aquela. Com o apoio de Terri, os Caxinauá revitalizaram-se enquanto povo. A antropóloga Mary Allegretti, que ouvira falar dos seringueiros através de Terri, narrou em sua dissertação sua surpresa ao encontrar no rio Tarauacá habitantes da floresta que não eram índios nem colonos, profundamente conscientes de sua condição de explorados pelo sistema de barracões, mas ao mesmo tempo identificados à vida na floresta, que não queriam abandonar. 0 sociólogo amazonense Carlos Teixeira (1980) explorou a dimensão simbólica e cultural da natureza na vida do seringueiro em outra tese de mestrado, tratando de um seringal no rio Madeira. Foi nessa época, no início de 1981, após os trabalhos pioneiros de Terri Aquino, Mary Allegretti e de Carlos Teixeira, que iniciei minha própria pesquisa no município de Cruzeiro do Sul [que na época abrangia todo o vale do Juruá até a fronteira peruana no rio Breu]. ${ }^{12}$ Por essa ocasião, porém, os empates dos seringueiros acreanos haviam tornado patente a sua aspiração por um modo de vida florestal independente dos patrões: tratava-se de obter o reconhecimento de seus direitos ao território, que é a base dessa forma de vida. É essa aspiração que o Conselho Nacional dos Seringueiros expressa quando reivindica a criação de Reservas Extrativistas. Os seringueiros, em suma, afirmam que não são meros apêndices de uma instituição arcaica e em desaparição.

\section{EQUILÍBRIo}

Vou agora traduzir essa negação em uma afirmação. A unidade de uso de recursos da floresta não é o seringal, e sim a colocação e os grupos domésticos que a constituem. É na colocação que são tomadas as decisões relevantes sobre o volume e a variedade da produção, o nível de povoamento e a conservação ambiental. É uma unidade de manejo, uma forma de organização social e 0 lugar de uma cultura que os seringueiros criaram durante aqueles "cem anos de solidão" em que foram esquecidos pelo mesmo capitalismo que para cá os trouxe sem passagem de volta.

\footnotetext{
${ }^{12}$ Após 1992, o município de Cruzeiro do Sul foi fracionado nos municípios de Cruzeiro do Sul, Rodrigues Alves, Porto Valter e Marechal Thaumaturgo.
} 
Falarei de colocações com base na pesquisa que realizei de setembro de 1982 a novembro de 1983, período durante o qual morei doze meses em seringais do alto Juruá. ${ }^{13}$ [Mais precisamente, no alto rio Tejo, no Riozinho da Restauração que foi minha base principal.] Trata-se de uma área de terra firma, já próxima à fronteira com o Peru, distante de uma semana por canoa da cidade de Cruzeiro do Sul e do hospital mais próximo, sem estradas nem ramais. Seu suposto proprietário nunca visitou o seringal [Restauração], que é arrendado por curtos períodos a patrões locais que buscam lucros rápidos. ${ }^{14}$

A vegetação [do vale do Tejo] é a floresta tropical com palmeiras e áreas de tabocal; os solos, de acordo com o levantamento Radambrasil, são do tipo cambissolo eutrópico; o relevo é de colinas separadas por grotas e grotiões. ${ }^{15}$ Distante da margem do Juruá, [o seringal Restauração, compreendendo os primeiros formadores do rio Tejo quando este se desvia do sentido oeste-leste para o sul] tem temperatura amena, é livre de piuns e catuquins, e suprido de água clara e fresca pelos igarapés e cacimbas. Estas são qualidades ambientais muito valorizadas pelos seringueiros de lá. 0 seringal Riozinho [abrangendo a bacia do afluente com este nome] ocupa cerca de 22.000 hectares, divididos em 26 colocações com uma média de 900 hectares por colocação. ${ }^{16}$ [0 seringal Riozinho, contudo, é

${ }^{13}$ Sou de Rio Branco, onde fiz o curso primário. Essa expedição foi meu primeiro retorno ao Acre desde que saí de lá em 1961, e minha primeira visita a Cruzeiro do Sul, a cerca de 500 km de Rio Branco, e onde não tinha parentes. Desfrutei, porém, da hospitalidade de Agaíse Messias e família.

${ }^{14} 0$ texto foi escrito em janeiro de 1988. Nessa época, quase todo o rio Tejo pertencia nominalmente a uma empresa sediada em São Paulo, e era arrendado por partes a "patrões" do município de Cruzeiro do Sul. Em 1988, o arrendatário principal era Orleir Cameli, que por sua vez sub-arrendava sub-seringais a outros. Essa estrutura de seringais maiores, subseringais e sub-sub-seringais encaixados uns nos outros é descrita em minha tese de 1993. Em 1988 a resistência dos seringueiros ganha em escala e alianças políticas graças à intervenção do Conselho Nacional de Seringueiros representado por Luiz Batista de Macedo. Em janeiro de 1990 é decretada a Reserva Extrativista do Alto Juruá, cujo núcleo político era o Rio Tejo inteiro.

${ }^{15}$ Sobre a morfologia, pedologia e estrutura florestal da Reserva, e muito mais, ver Carneiro da Cunha e Almeida (2002).

${ }^{16} \mathrm{Na}$ época não havia GPS (introduzidos na década de 1990), nem dispunha de imagens de satélite. Quando fiz a pesquisa de campo nas colocações (1982-1983 e 1987), usei como base cartográfica as cartas do Departamento de Produção Mineral na escala de 1:250.000 baseadas em imagens aéreas do Projeto Radambrasil. Essas cartas não traziam nenhum toponímico. Os mapas do IBGE ("ao milhonésimo"), por outro lado, identificavam erroneamente todos 
apenas um dos seringais subordinados ao seringal Restauração, cuja sede, com o barracão principal e residência do gerente e guarda-livros, ficava na Foz do Riozinho da Restauração. Esses seringais secundários, cada um com seu pequeno depósito de mercadorias e um pequeno patrão, frequentemente um seringueiro ou ex-seringueiro mais produtivo, correspondiam a cada um dos formadores do alto rio Tejo: seringal São Francisco (rio Dourado), Riozinho e Manteiga (este último em um afluente do Riozinho), Camaleão (no igarapé com esse nome), Vitória (últimas cabeceiras do Tejo) e Machadinho (o último afluente do Tejo, e que é um paranã com a pecular vegetação de campina, formação que se encontra também no alto rio Bagé) $].{ }^{17}$

Nas colocações do Riozinho havia em média duas a três casas. Assim, enquanto uma colocação ocupava cerca de 900 ha, à casa correspondiam de 300 a 450 ha. Cada casa abrigava um grupo doméstico de 5,8 membros em média. Isso leva a densidades demográficas entre 1 e 2 habitantes por quilômetro quadrado. Tal número, que pode parecer baixo à primeira vista, reflete mecanismos importantes de equilibração ambiental e social nas colocações, como mostrarei adiante. ${ }^{18}$

Os moradores da colocação podem atuar como uma equipe de caça, e como equipe de trabalho para certas tarefas coletivas, como abrir roçados e fazer farinha na casa-de-farinha em colônias que agrupam os roçados de cada grupo doméstico. A carne de caça é compartilhada no plano da colocação, mesmo que tenha sido obtido por um caçador de uma casa. [Chama-se a isso de vizinhar

os rios e localidades do alto Tejo (a começar pelo Riozinho, usando denominações já em desuso associadas a cursos d'água errados (por exemplo, dava ao Riozinho o nome de "Igarapé Pedro Gomes", na verdade antigo nome do atual Rio Bagé que era dado a outro curso d'água). Usei bússola e cronômetro para refazer a carta muda do DNPM e identificar corretamente os igarapés e sedes de colocação, e essa base cartográfica artesanal foi incorporado na base cartográfica pioneira elaborada no CEDI por Alicia Rolla com minha colaboração, servindo para o Cadastro de Moradores, realizado em 1991, como parte do processo de implementação da Reserva Extrativista do Alto Juruá, e também para o mapa realizado pela Embrapa Meio Ambiente em 1989.

${ }^{17}$ Mapas no Anexo 2. Vejam-se os capítulos correspondentes em Carneiro da Cunha e Almeida (2002). Esses mapas beneficiaram-se da base cartográfica elaborada no CEDI por Alicia Rolla com ARC-Info, com reelaboração feita por mim usando a versão ARC-View sob licença da Universidade de Chicago.

${ }^{18}$ Essas densidades eram as mais altas de rio Tejo, e refletiam a abundância e produtividade das seringueiras dessas cabeceiras. Por outro lado, a distribuição de casas no Riozinho tinha um efeito negativo sobre a abundância de caça, fazendo com que esse seringal, famoso pela produtividade de borracha, fosse também na época chamado de "rio da fome". 
a caça. ${ }^{19}$. As casas de uma colocação são na maior parte dos casos de chefes de família ligados por laços de parentesco [assim, a casa de um casal mais velho, ou de viúva, e as casas de filhos ou genros; ou ainda casas de irmãos e de irmãs casados, formando assim como que casas ampliadas.] Colocações próximas interligam-se por laços de parentesco, casamento, compadrio, cooperação e comércio. Reúnemse em mutirões e festas, sem respeitar fronteiras de seringais, e transpondo mesmo as bacias hidrográficas (nas colocações mais distantes do Riozinho era comum visitar amigos e parentes na vila Jordão, na foz do afluente do Tarauacá.). Essas formas de sociabilidade são importantes para contrabalançar as tensões latentes entre vizinhos, alimentadas muitas vezes por intrigas e fofocas, e que podem se tornar questões. São questões de roçado (porcos que invadem roças), em torno de mulheres (filhas e irmãs que engravidam, que são roubadas, que deixam o marido), caçadas (animais perseguidos numa colocação que são abatidos à frente da casa dos moradores de outra colocação), e estradas de seringa (que se entrelaçam e crescem, são repartidas e emprestadas, sem que haja fronteiras fixas entre territórios de casas e mesmo de colocações). Essas tensões atuam no sentido de rarefazer os moradores das colocações que competem, quando seu número cresce, por recursos que são limitados. Em suma, o sistema social das colocações está longe de reduzir-se às relações entre seringueiro e patrão. Ele possui regras próprias e locais. ${ }^{20}$

Isso nos leva ao tema principal, que é a colocação como unidade de uso dos recursos naturais.

0 recurso natural mais óbvio nas colocações são as seringueiras agrupadas em módulos que são as estradas de seringa. 0 destaque para esse recurso vem do fato de que ele constitui a base da pretensão dos patrões à propriedade do seringal,

\footnotetext{
${ }^{19}$ Uma descrição bem detalhada do sistema de vizinhança encontra-se na tese de doutorado inédita de Augusto Postigo (2010).

${ }^{20}$ Para descrições mais recentes e detalhadas do modo de vista de seringueiros e ex-seringueiros nas florestas do alto Juruá, vejam-se as dissertações e teses seguintes para as quais apenas indico os nomes de seus autores e o tema principal: dissertações de Eliza Lozano Costa (sistema político), Andrea Martini (família e gênero), Gabriela Jahnel (religião), Mariza Araújo (uso em comum de recursos), Carla Dias (caçadores), Augusto Postigo (alfabetização), Alexandre Goulart (cooperativas) e Roberto Rezende (urbanização), e teses de Mariana Pantoja Franco (história de vida de seringueiros indígenas), Christina Scheibe Wolff (história de mulheres), Eliza Lozano Costa (sistema político) e Augusto Postigo (cartografias e cosmologias). Vejam-se também os capítulos da Enciclopédia da Floresta com colaborações destes autores, bem como de autores indígenas e seringueiros (CARNEIRO DA CUNHA e ALMEIDA, 2002).
} 
embora de fato nenhum papel exerça na abertura ou na conservação das estradas. A "renda da estrada de seringa" é a expressão simbólica dessa pretensão. ${ }^{21}$

Para os seringueiros, no entanto, a colocação é mais que um conjunto de estradas de seringa. É um microcosmo social e natural, concebido como idealmente autônomo em produtos agrícolas - farinha, tabaco, milho, café, açúcar -, em carne de caça, em materiais de construção. E em oportunidade de trabalho para uma família ampliada em crescimento. ${ }^{22}$

Para realizar o objetivo [de uma autarquia ideal], uma colocação deve abrangerum conjunto de diferentes recursos distribuídos por zonas horizontalmente dispostas. Deve conter rios ou igarapés, de preferência compoços piscosos (onde as pauseiras abrigam peixes que subiram os igarapés nas piracemas anuais), praias e barrancos (onde são plantadas a melancia e os gerimuns, e também feijão e milho), bem como terra firme (onde são postos os roçados de mandioca). Devem contar com mata virgem com seringueiras, palmeiras e fauna abundante (uma mata com muita taboca constituía uma desvantagem). Deveria ter solo de tipo barro preto ou de barro areiúsco para os seus roçados.

$\mathrm{Na}$ mata bruta são iniciados roçados todos os anos. Esses roçados de mandioca, plantada em associação com milho no primeiro ano, e cercados de bananais perenes, passam por ciclos de manejo que em muitas colocações duravam de três a seis anos, passando então ao estágio de capoeiras que ainda eram produtivas por dois a três anos. Finalmente, as capoeiras são abandonadas por períodos que eram apontados como de quatro anos ou mais, revertendo depois à mata bruta cuja idade era difícil determinar. Esse manejo de roçados combinase a outros, como o dos campos de pasto, que começam como roçados de arroz e

\footnotetext{
${ }^{21}$ Este texto não era o lugar para uma descrição detalhada, mas cabe acrescentar o seguinte ponto. Do ponto de vista do barracão, cada colocação era dotada de um certo número de estradas de seringa, e um seringueiro adquiria direito de explorar estradas mediante pagamento da renda por cada estrada de seringa arrendada. Assim, numa colocação com nove estradas, era comum que duas casas arrendassem duas a três estradas, restando algumas estradas vadias. Contudo, na prática o número e tamanho das estradas, e sua repartição, era assunto dos seringueiros, que recursavam ou ampliavam suas estradas de seringa ao longo do tempo. ${ }^{22}$ Por "família ampliada", eu apontava o conjunto de grupos domésticos aparentados entre si e que compartilhavam uma colocação. Esse conjunto crescia e diminuía com o tempo, pela formação de novos grupos domésticos (novas casas) ou pela saída de um ou mais grupos de uma colocação. Havia assim um ciclo de vida das colocações. Ver mais detalhes em Almeida (1993).
} 
viram pastos nas vizinhanças das casas; ou os ciclos anuais de plantio de milho, melancia e feijão nos barrancos; ou o uso da várzea para plantar tabaco.

Os terreiros também compreendem, com o campo, a margem do igarapé e a orla da mata, uma unidade de manejo - compreendendo hortas, fruteiras, palmeiras, lenha e cultivos que o expandem. A criação doméstica tira partido da fronteira entre área doméstica e floresta: os patos no igarapé, os porcos na mata e limpando os sujadores, as galinhas ciscando os resíduos deixados pela primeira derrubada do terreiro e que incluem a lenha usada no fogão [de barro].

A mata, que é fonte de terreiros para roçados anuais, é também território de caça e de coleta com seu estoque bem conhecido e explorado pelos seringueiros que, ao longo dos caminhos, estradas e varadores, conhecem cada madeira, cada oco de abelha, cada cacho de patuá ou de açaí, cada pau de envira, cada pau de âmago, cada palheira, e cada vareda de paca e de outros animais. ${ }^{23}$ A caça de animais da mata não serve só de alimento aos moradores, aliás, mas também para cachorros (que ganham entranhas, mas não ossos porque a dispersão desses pode darpanema ao caçador) e bichos domésticos. Os animais selvagens, por sua vez, alimentam-se dos roçados de mandioca e das capoeiras (seringueiros queixavamse que uma quarta parte de roçados era comida de pacas, pacas-de-rabo, veados). Observamos assim que o igarapé, o terreiro, o campo, os roçados, as capoeiras e a mata se interligam em cadeias de delicado equilíbrio. Não é fácil mexer em um hábito dos seringueiros sem interferir em outros. ${ }^{24}$

Roçados demais reduziriam o tempo de regeneração da mata e degradariam a floresta; animais silvestres demais são ameaça aos roçados - assim como porcos ou gado em doméstico em demasia -; muita caçada ou superexploração das seringueiras tem como consequência a queda no rendimento dessas atividades, sendo então preciso gastar muitas horas procurando o animal, e cortar a seringueira cada vez com escadas mais altas.

\footnotetext{
${ }^{23}$ Maira Smith e Daniela Vidalenc, na época estudantes de biologia na graduação, realizaram um estudo detalhado da percepção dos recursos vegetais por homens e mulheres em colocações do alto Tejo (SMITH; VIDALENC, 1997).

${ }^{24}$ Essa ideia foi afirmada por Philippe Descola a propósito dos Achuar. A metodologia de Descola, combinando a análise de dados quantitativos à análise de significações, foi uma importante inspiração para minha pesquisa de julho a setembro de 1987 (DESCOLA, 1983; ALMEIDA 1988).
} 
A extração pode ser, em suma, degradativa. ${ }^{25}$ A economia extrativa das colocações possui mecanismos de equilíbrio. 0 primeiro consiste em alertas. Terreiros que empobrecem, pragas que invadem a casa, conflitos por estradas, caça escassa e seringueiras improdutivas são motivos para abandonar uma colocação. Gado ou porcos em excesso são abatidos quando ameaçam roçados, meus ou do vizinho. Esse primeiro mecanismo reduz a pressão sobre os recursos naturais através da diminuição da população. Gera um padrão desigual de ocupação das colocações [e pode ser verificado exatamente checando esse padrão desigual de ocupação], e permite que surjam micro-santuários para regeneração da caça e da floresta. Entre seringais, áreas assim constituem verdadeiros refúgios. Esse mecanismo, porém, supõe que:

- Haja floresta disponível, acima da capacidade de sustentação de curto prazo;

- Não haja propriedade individual da terra.

Esse é o fundamento da proposta de Reservas Extrativistas sem lotes de floresta individualmente possuídos por famílias, e com as colocações (territórios de usados por um número flexível de casas) como unidades de exploração. ${ }^{26}$

\footnotetext{
${ }^{25}$ Não fazemos, portanto, uma distinção entre técnicas de extração e coleta, assim como não distinguimos tecnicamente a agricultura de roçados cujo produto se destina ao mercado e aquela cujo produto se destina ao consumo doméstico. Sob extração incluímos a caçada (incluindo aqui técnicas diversas que não são referidas por esse nome), a coleta de látex (além de óleos como o da copaíba), de madeira (incluindo folhas de palmeiras, enviras e cipós), de frutos (açaí, bacaba, buriti) e vários modos de obter peixe do rio. 0 látex coletado na mata era destinado ao fabrico de borracha, mas era usado também para fazer sapatos, sacos (o látex de caucho era também usado para esse fim) e outros fins. Analogamente, o produto dos roçados, como a farinha, embora normalmente destinado à alimentação do grupo doméstico, podia ser vendido. Em todos esses casos objetos extraídos-coletados inserem-se em diferentes circuitos sociais: o âmbito doméstico, as relações de vizinhança (trocas obrigatórias) e de troca (em espécie, em trabalho) e o comercio fiado junto ao barracão. Os objetos ganham formas distintas conforme sua posição nesses circuitos.

${ }^{26}$ A Reserva Extrativista situa-se no mesmo nível de morfologia social que o antigo seringal. Ela deve substituí-lo como unidade territorial abrangente, e também como unidade administrativa e de regulação coletiva. Ela introduz regras escritas e processos democráticos em lugar do poder de classe de patrões de barracão. Um instrumento importante na reserva extrativista é 0 Plano de Uso. Os tópicos seguintes dizem respeito a regras conscientes ou não relacionados ao uso dos recursos comuns no território da Reserva.
} 
Há dois outros mecanismos importantes de controle ecológico: normas culturais e normas conservacionistas. Os seringueiros do Riozinho utilizam-se de cerca de 50 espécies animais silvestres distintas, mas evitam o consumo de espécies animais entre mamíferos, aves e répteis [em várias faixas de peso, incluindo-se aqui preguiças, mambiras (além de bandeiras e tamanduaís), pacas-de-rabo, onças e de modo geral predadores terrestres e aquáticos ("bichos estranguladores" como a ariranha), "coelhos", ratos-coró (silvestres e especialmente de tabocais), mucuras, soins]. Quatipurus, embora de pequeno peso, eram apreciados. Algumas evitações são universais, isto é, valem para qualquer pessoa [mambira, pacade-rabo, rato-coró eram bichos repugnantes para o consumo]; havia animais evitados sazonalmente [o tatu magro tinha reputação de mau sabor, que alguns associavam a possível feitiço]. Outras evitações diziam respeito a uma condição do consumidor: incluíam-se aqui os tabus de gravidez, de puerpério, de doença, de picada de cobra - nesses casos, evitavam-se os animais reimosos que podiam ser peixes ou mamíferos. [Outros casos de evitação consistiam em restrição na própria atividade de punção de vida animal por razões associadas ao risco de panema -e dias da/do Caipora, máximos de animais predados, respeito ao corpo do animal, ou de feitiço, limitando a esfera de vizinhança]. Todos esses mecanismos têm em comum alguma forma de abstenção ou restrição ao acesso a entes da natureza. A abstenção [seja por qualquer motivo] pode ser considerada como uma técnica extrativa que consiste em reduzir a produtividade, diametralmente oposta a técnicas produtivas cuja tônica é aumentar a produtividade. No mundo moderno, a técnica produtiva associa-se a éticas consumistas cujo pressuposto é que a natureza pode ser arbitrariamente alterada [em seu rendimento] sem custos. ${ }^{27}$

Um terceiro e importante mecanismo conservacionista são as normas. Estas podem ser obrigatórias (caso das normas de corte de seringueiras), consensuais (caso de normas de uso do patoá, bacaba, copaíba etc.) e não-consensuais (caso de caça de filhotes e de veadas, por exemplo). ${ }^{28} 0$ problema que os seringueiros

${ }^{27} 0$ que estou dizendo aqui pode ser parafraseado com a linguagem da teoria ecológica dos
recursos naturais renováveis. Aqui, atingir o máximo de produtividade de um recurso renovável
significa fazer uma retirada "ótima" do recurso. Essa retirada "ótima" sempre é inferior
à retirada máxima possível em um momento dado (hoje), mas ela maximiza a retirada
sustentável a longo prazo, mediante a abstenção da retirada máxima hoje (DASGUPTA;
HEAL, 1979). Por isso estou falando seriamente ao afirmar que tecnologias extrativistas são
abstencionistas em sua natureza. Por outro lado, o que chamamos aqui de técnicas produtivas
são sempre apoiadas em atividades extrativas, amiúde irreversíveis e de curta duração.
${ }^{28}$ Nos seringais antigos havia normas desse tipo. Cabia a mateiros fiscalizar o corte de 
enfrentam é o de tornar obrigatórias e consensuais essas normas, explorando ao mesmo tempo com mais liberdade seus recursos antes "proibidos" e adotar políticas conscientes de limitação da população. ${ }^{29}$

A exposição anterior sobre o uso de recursos naturais na colocação não teve a intenção de fazer a apologia do preservacionismo de índios e seringueiros. Eles saberiam fazê-lo melhor do que eu.

0 problema que as reservas extrativistas terão a considerar é, por exemplo, como redistribuir as famílias na colocação sem arbítrio, quando a qualidade de vida elevar-se notavelmente nelas, sobretudo se as "reservas" se converterem em ilhas num mar de colonos miseráveis; como controlar as pressões de caçada, quando o tempo livre for maior, e sem fiscais do IBDF; como substituir tabus por um uso flexível dos recursos. Acima, disse que era preciso destruir o seringal, conservando as colocações. Trata-se também de implantar nestas formas de poder de seringueiros, a partir das quais os seringueiros se organizem e substituam 0 barracão como sede de poder.

\section{III. [A QUALIDADE DA VIDA]}

A questão que poderia ser agora colocada é: tal equilíbrio é uma situação desejável? Apesar de ecologicamente estável, caso "tudo dê certo", a economia agroextrativista de seringueiros é capaz de sustentá-los em níveis adequados e a custos razoáveis? Não interessaria, de fato, manter um equilîbrio de fome e supertrabalho. ${ }^{30}$

seringueiras. Roçados não podiam jamais incidir em territórios de estradas.

29 Todo grupo camponês conhece mecanismos de auto-limitação da população, que vão dos de natureza malthusiana (a alta mortalidade infantil) à emigração: filhos que não encontravam estradas para ocupar, ou que não buscam outras terras para plantar (ALMEIDA, 1995). Outras normas importantes: as que regulam o acesso comum a zonas de caça, a lagos e rios de pesca, e a possibilidade de mobilidade espacial de locais de moradia e de locais de roçado.

${ }^{30}$ Aqui, passa-se do tema da estabilidade para o da desejabilidade. No fundo, trata-se de comparar um quadro de bem-estar possível nas colocações a partir das restrições dadas pela técnica extrativa sujeita a regras de equilíbrio indicadas na seção anterior (o que impõe limites seja à população total, seja ao nível de produto agrícola, seja ao nível de produto extrativo - tema tratado na tese de doutorado com o instrumental da programação linear), ou seja, o horizonte de possibilidades no interior do sistema de uso tradicional, com o "desenvolvimento" nos quadros da Reserva Extrativista. 
Para propiciar uma discussão desse ponto, darei alguns dados sobre a economia doméstica das colocações, sem pretender construir um modelo de validade geral..$^{31}$

Cada casa possuía roçados em três fases: roçado novo [a partir da mata bruta ou de capoeira de roçado antigo], roçado em amadurecimento ou maduro plantado no ano anterior [de onde já se começava a arrancar segundo a qualidade da roça], e "arrancador", do qual era retirada a mandioca para ser convertida em farinha, e no qual era possível replantar uma ou duas vezes ["plantar no arrancador"].

Esse sistema podia produzir, sem degradação, [toda a farinha necessária para alimentar um grupo doméstico, e que girava em 1.200 quilos anuais]. Parte da mandioca ia para a alimentação de animais, enquanto outra parte era depredada por pacas ou cotias.

[Para implantar esses roçados, incluindo-se aqui as tarefas de roçar, derrubar, queimar-encoivarar e plantar, o pessoal das casas ocupava boa parte dos meses de agosto a outubro, distribuídos entre julho e setembro de cada ano. ${ }^{32} \mathrm{~A}$ atividade de preparo de roçados ocupava de dois a três dias por semana nessa fase mais intensiva, com uma jornada de trabalho de cinco a seis horas em média. ${ }^{33}$ Ao lado do trabalho nos roçados, a fabricação da farinha tomava um tempo considerável do pessoal das casas, exigindo cerca de dois dias na casa-de-farinha a cada quinzena]..$^{4}$

${ }^{31}$ No âmbito da exposição oral, os parâmetros numéricos indicados são por um lado aproximados e por outro se referem a minha pesquisa de campo no Riozinho do alto Tejo. Detalhar a exposição nesta parte aumentaria desproporcionalmente o texto.

${ }^{32}$ No texto original, dizia: "Esses roçados exigiam cerca de 30 dias de trabalho por casa". Esse número resultava de vários cálculos intermediários a partir de atividades de diferentes membros da família distribuídas por dias da semana em várias atividades ao longo de três meses. Não incluía a atividade de limpar o roçado, feita frequentemente por mulheres acompanhadas de crianças em "pedaços de dia" Sobre o assunto, ver o Pantoja Franco et al. (2002).

${ }^{33} \mathrm{Na}$ minha experiência, seringueiros-agricultores trabalhavam sob o sol a pino nos roçados. Lembremos que o trabalho da seringa era feito à sombra da floresta, na madrugada e pela manhã. 0 trabalho assalariado agrícola, e também o de "colonos" (agricultores de lotes do Projeto Santa Luzia) era visto sobre esse prisma como pior do que o do seringueiro.

${ }^{34}$ Trata-se em tudo isso de um modelo do uso de trabalho de uma família, isto é, de uma abstração feita a partir de dados etnográficos. No texto original, eram somados trabalhadores por dia, multiplicados por dias por mês e por meses de atividade. 0 objetivo final era, no corpo da tese, mostrar como a economia doméstica de seringueiros distribuía de maneira 
[A caçada (de porquinhos-do-mato, de veados, de tatus) proporcionava carne da mata para a alimentação, apoiada em uma rotina semanal de um a dois com caçada como atividade principal, e frequentes saídas no fim do dia, principalmente no "inverno" (chuvas), a passo que no "verão" a pesca (com uso de tarrafas ou arpões e ganchos nos igarapés, além de oaca) tornava-se a fonte principal de proteínas]. 35

A produção de borracha era em média de 600 a 700 quilos anuais por casa no Riozinho da Restauração [número acima da média para o Vale do Juruá, que era de cerca de 400 quilos de borracha conforme dados do Censo Agropecuário de 1970 e de 1980], incluindo-se aí os dias de preparo da estrada e de sangria das árvores seguida de defumaçao [essa era a técnica ainda em uso em 1982-1983]. Com essa produção anual, na época da pesquisa de campo [1982-83], uma casa podia pagar a renda de estradas de seringa [33 quilos por estrada, para uma média entre 2 e 3 estradas por casa] e adquirir a estiva ou bens básicos, isto é, o mínimo de mercadorias necessárias à vida e ao trabalho, tais como sal, sabão, querosene, munição etc. [na época, um quilo de borracha correspondia a US $\$ 1,80$ aproximadamente, o que daria para 650 quilos de borracha um correspondente em valor de US\$1.250,00 em poder de compra, a preços inflados do barracão]. Havia um conflito constante entre seringueiros e patrões, girando em torno da exigência patronal de que todas as mercadorias fossem compradas no barracão no interior do sistema de prazos anuais de pagamento, pagando em borracha após subtrair o valor em borracha do débito anual do produto anual em borracha armazenado na casa do seringueiro para pagamento do patrão (e as decisões dos seringueiros de comprar de regatões pequenas quantidades, pagando nesse caso em borracha e à vista). ${ }^{36}$

variável o tempo de trabalho doméstico disponível entre a atividade de extração de látex, de agricultura e de caça-coleta. Essa variação dependia de um lado da fase de vida do grupo doméstico (CHAYANOV, 1986), e por outro lado da relação de forças entre seringueiros e patrão (tese inspirada em Marx), e finalmente em estratégias associadas a histórias de vida e a metas de consumo diferenciadas entre as casas. Ver também Almeida (1996).

${ }^{35}$ Também aqui usamos no texto original estimativas numéricas que são deslocadas aqui. Elas eram baseadas em parâmetros obtidos em entrevistas realizadas em 1990 em uma amostra de 69 residências dentre 960 casas entrevistadas durante o cadastro de moradores da Reserva Extrativista do Alto Juruá (ALMEIDA, 1992). Os dados registrados por seringueiros em cadernos de campo a partir de 1995 e até 2005 aproximadamente permitem avaliar com muito mais realismo a situação (RAMOS, 2005; ALMEIDA e PANTOJA FRANCO, 2005).

${ }^{36}$ Com a criação da cooperativa em 1989, os seringueiros passaram a poder comprar de 
Observe-se que havia grande variação entre as casas. Os números acima são médias que não traduzem de fato a diversidade de decisões efetuadas por cada grupo familiar [no interior de limites mínimos e máximos]. Nosso objetivo foi indicar que, com uma quantidade anual total de cerca de 210 dias de trabalho da família, em média, essa podia suprir suas necessidades de alimentação (roçados e caçadas), adquirindo ainda bens básicos para manter um padrão de vida "mínimo" no consumo de bens importados - respeitando ao mesmo tempo o equilíbrio ecológico das colocações. Além disso, algumas casas, com maior número de membros ativos [e, portanto, com uma maior proporção de trabalhadores em relação a consumidores], ou com determinadas condições de localização [zonas com estradas de seringueiras virgens e altamente produtivas, ou com caça abundante], podiam produzir quantidades de borracha bem mais altas, com mais de 1.000 quilos por seringueiro ativo. Outras casas implantavam grandes roçados, suficientes para alimentar reuniões de muitos seringueiros e para dar mandioca a necessitados. Assim, algumas casas podiam, além de produzir um mínimo de alimento e de mercadorias, comprar um boi [frequente como dote de filhas], ou um motor a gasolina [motores de 8 HP da marca Briggs-Stratton, ou Montgomery, usados em casas-de-farinha, ou para empurrar pequenas canoas para uma tonelada de carga], ou ainda rádios, vitrolas, máquinas de costura e outros "móveis de valor". Outras casas preferiam fazer menos borracha e adquirir menos itens importados, concentrando seus esforços em roçados amplos que garantiam fartura e hospitalidade, reforçando o prestígio de seus moradores. Havia, finalmente, seringueiros qualificados como "preguiçosos" pelos patrões, e que empregavam seu tempo na caça e na pesca, dedicando ao fabrico de borracha o mínimo necessário para adquirir os meios de trabalho e de caça (cartuchos e chumbo), bem como o mínimo absoluto de bens de consumo (sal, sabão etc.). [Num dos vértices de um extremo, a casa de Sr. Nascimento produzia acima de 2.000 quilos anuais, e até quatro toneladas quando seus quatro filhos adultos estavam ativos sob o controle paterno - resultando numa casa que possuía motores, fogão a gás, colchão de molas, casa e conta de poupança em Cruzeiro do Sul. Outro extremo, a casa de Farias, possuía grandes roçados, suficientes para alimentar reuniões de muitos seringueiros e para dar mandioca a necessitados.

cantinas cooperativas, sem pagar "juros" sob os quais incluíam indistintamente lucros brutos, juros e correção monetária; os seringueiros esperavam que a cooperativa fornecesse mercadorias ao preço de Cruzeiro do Sul, sem correção monetária, ao prazo de um ano - mas continuaram a comprar dos regatões comprometendo a borracha que deveria saldar os débitos para com a cooperativa que se tornou rapidamente insolvente. 
No terceiro vértice desse triângulo de possibilidades, a casa de Chagas produzia um mínimo de borracha para comprar a estiva básica e aparentava pobreza pelos padrões locais. A expedição de Manuel Banha para cobrança de dívidas de 1986-87 registrou cenas de cobrança de máquinas de costura e vacas de leite para pagar supostas dívidas de borracha ao barracão - foi contra essa medida que Chico Ginu, então delegado sindical, organizou um movimento de resistência bem-sucedido]

Esses dados indicam que, menos num seringal de tipo tradicional, onde a economia das colocações era subordinada às relações de dívida para com 0 barracão, os seringueiros conseguiam conquistar uma margem de autonomia na organização de seu tempo e na utilização de seus recursos. Eles reagiram de várias maneiras às tentativas do patrão a restringi-los a uma atividade especializada e dirigida apenas à produção de borracha. [0s patrões não conseguiram subordinar materialmente os seringueiros, porque não controlavam o processo técnico de extração nem em sua rotina diária nem do ponto de vista técnico; e não conseguiram subordinar formalmente os trabalhadores porque estes rejeitaram sempre as tentativas de transformá-los em assalariados - algumas dessas tentativas registradas por mim durante 0 trabalho de campo; a explicação principal para esse quadro era a existência de uma vasta quantidade de terras de alta produtividade natural face à população, e à impossibilidade de controlar pela força o trabalho extrativo dispersos por enormes áreas de floresta em zonas de difícil acesso e interligadas de inúmeras maneiras por trilhas da floresta desconhecidas pelo pessoal dos barracões].

Assim, do ponto de vista do barracão, o seringal subutilizava os recursos naturais e humanos. [Em 1982-83, no seringal Restauração como um todo, incluindo o Riozinho, Dourado, Manteiga, Camaleão, Vitória e Machadinho, além da sede Restauração e do Boa Hora, apenas dois terços das estradas eram arrendadas. Os seringueiros cortavam em média quatro dias semanais durante cerca de 60 dias anuais. Quando aumentava o número de trabalhadores numa casa, cada um individualmente reduzia a intensidade do trabalho [assim, uma casa com um adulto e dois filhos com mais de doze anos, onde eu residia, uma produção próxima a uma tonelada de borracha anual era obtida com uma rotina de sangria de estradas na qual cada seringueiro individualmente cortava em geral metade de uma estrada em cada jornada diária, reduzindo o tempo de trabalho diário por seringueiro, e no entanto conseguindo um aumento na produtividade da casa como um todo]. Para os seringueiros, ampliar unilateralmente a produção de borracha significaria abandonar os roçados e a caçada, e consequentemente 
amarrar-se ao débito no barracão [Essa era o modelo ideal do barracão: um seringueiro solteiro que compraria todo o alimento do barracão, dedicando-se apenas a fazer borracha, em uma colocação em que todas as estradas estariam arrendadas e ocupadas produtivamente, sem estradas vadiando.] 0 que para os patrões significava baixa produtividade, para os seringueiros significava decisões prudentes [não exceder numa colocação o número de famílias que permitisse ocupar seus filhos adultos] e econômicas (manter a diversidade produtiva das colocações, distribuindo a atividade familiar entre caçada, agricultura e extração de látex). A estratégia dos seringueiros consistia em tornar máxima a diversidade de seu nicho ecológico, e utilizá-la para aumentar o bem-estar de suas famílias.

0 alvo dos patrões, ao contrário, era aumentar o produto bruto a curto prazo. ${ }^{37}$ Em consequência dessa lógica, os patrões exerciam pressão no sentido de aumentar o número de seringueiros, de aumentar a produção bruta por estrada, e de expulsar os seringueiros tidos como "preguiçosos". Usavam para isso meios que iam desde a cobrança de preços abusivos (mais para manter endividados os seringueiros do que para garantir sua própria capacidade de pagar ao banco), ao emprego de tropas policiais para cobrar (em borracha) débitos em atraso. Buscavam ainda retirar os marreteiros do seringal, com apoio de juízes e de policiais dispostos a receber propina por atividades de fim de semana. Essas pressões sobre a economia agroextrativa das colocações significavam ao mesmo tempo pressão sobre os recursos naturais (depredação) e pressão sobre os recursos humanos (superexploração). Os seringueiros resistiam à depredação ecológica não apenas por amor à natureza, mas também para resistir assim à depredação de seu próprio trabalho.

A esta altura, torna-se claro que questões de manejo ambiental e de viabilidade econômica tornam-se questões políticas. Para lutar contra a taxa crescente de degradação ambiental e contra a tendência ao aumento da taxa de

\footnotetext{
${ }^{37} 0$ lucro dos patrões dependia diretamente do volume bruto de borracha que pudessem oferecer ao banco como garantia antecipada do financiamento anual - com juros a 3\% e sem correção monetária, quando a inflação atingia 100\% anuais. Esse volume de borracha era estimado em função do número de seringueiros que ocupavam estradas de seringa mediante pagamento da renda. 0 adiantamento de dinheiro de parte dos bancos (Basa, Banco do Brasil) assegurava lucros financeiros e comerciais aos patrões mesmo sem comprar mercadorias, ou vendendo mercadorias adquiridas com isenção de impostos por empresas registradas em Manaus. Toda a produção tinha compra assegurada. Sem competição, não estava em jogo a produtividade extrativista e sim a produção bruta (o produto anual bruto de borracha que determinava 0 valor do empréstimo bancário adiantado anualmente).
} 
exploração de seu trabalho, os seringueiros já resolveram substituir o sistema dos barracões pelo controle livremente exercido sobre suas florestas, através da implantação das Reservas Extrativistas. Para isso, precisam de aliados políticos - assim como os patrões, que sempre foram beneficiários com subsídios de todo tipo, financeiros a jurídicos, para exercer um monopólio comercial auferindo ao mesmo tempo uma "renda" com características pré-capitalistas [em espécie, fixada em uma quantidade de quilos de borracha, independente do produto ou dos preços de mercado, sem relação com a taxa de lucros ou de juros vigente no mercado]. Para os seringueiros não se trata de pedir subsídios. Trata-se de obter o reconhecimento de seus direitos enquanto usuários dos recursos da floresta e enquanto produtores extrativistas.

\section{[IV. Exploração e Poder no Seringal]}

[Para entender melhor a última observação acrescento observações analíticas sobre o seringal no período e no local em que observei seu funcionamento de perto. 0 seringal era, antes de mais nada, uma organização territorial e social apoiada no trabalho de seringueiros, e que visava lucros para uma classe de patrões. Na minha tese de doutorado, procurei mostrar que esses lucros eram grados de duas maneiras: a cobrança de uma renda pelo uso da floresta (renda de estradas de seringa, que, no entanto, implicava no direito de uso para todo o território florestal compreendido por elas) e lucros comerciais e usurários apoiados no monopólio/monopsonio do comércio de borracha e de mercadorias (o barracão arrogava-se a posição de único vendedor de mercadorias e de único comprador de borracha). A sustentação dessas duas instituições era 0 poder político local dos patrões (não havia até 1977 sindicatos rurais, e só patrões tinham acesso a advogados e tribunais, que costumavam servir a seus interesses; a igreja no Alto Juruá era também intimamente aliada aos patrões, cujo poder estendia-se ao controle de notícias pela estação radiofônica federal).

É importante observar que não era parte desse quadro o controle direto da economia doméstica das colocações por parte do barracão ou sede de seringal. Procurei demonstrar essa tese analisando detalhadamente por quem, quando e como eram tomadas as decisões de arrendar estradas, quem e como era feitos os investimentos na abertura e conservação de estradas de seringa, quem comprava os instrumentos de trabalho, e como eram tomadas as decisões de uso do trabalho doméstico - não assalariado - de cortar seringa, botar roçados, 
caçar, construir casas, fazer viagens. Prestei especial atenção ao registro das diferentes combinações de uso de estradas de seringa pelos membros das unidades domésticas (quantidade de estradas em uso por casa, quantificadas por número de árvores cortadas, e trabalhadores efetivos empregados nelas), nível de produção por unidade doméstica e volume de dívidas também por unidade doméstica.

0 resultado indicava que (1) no conjunto de cerca de 70 casas de seringueiros do Riozinho havia uma grande variação na ocupação das estradas por colocação, sendo que na maioria dos casos havia estradas "vadiando" (em tese, mais famílias poderiam ocupar cada colocação); (2) o índice de estradas de seringa utilizadas por trabalhador era claramente inferior ao máximo possível (em tese, os trabalhadores poderiam fazer mais borracha). A ocupação efetiva das colocações (i.e. o número de grupos domésticos por colocação), bem como a intensidade do trabalho (i.e. número de seringueiras cortadas por trabalhador), dependia em parte do estágio de desenvolvimento do grupo doméstico: em famílias jovens havia um único seringueiro (o jovem marido) com plena capacidade para a extração de látex, mas que precisava dividir seu tempo com os roçados e a caçada (a produtividade individual era "média") - a hipótese de Chayanov, reencontrada por Amartia Sen.

Esse resultado combinava-se com a hipótese de que a alocação do esforço familiar entre extração de borracha (e rendimento expresso não monetariamente, mas em aquisição de "bens duráveis" e "de luxo" além de "necessários"), farinha (correspondente a volume de roçados por pessoa) e caça não era governada pelo barracão, e sim por escolhas domésticas. Expressei essa tese em um diagrama de "espaço de possibilidades de produção" em um espaço com duas dimensões. No eixo horizontal, indiquei o nível de produtividade de borracha (indicador da atividade extrativa) por grupo doméstico (alternativamente, por trabalhador). No eixo vertical, o nível de produtividade de farinha (indicador de atividade agrícola) por grupo doméstico (alternativamente, por trabalhador). Há um ponto no diagrama cuja abcissa representa a produção mínima de borracha necessária para cobrir os custos de produção (tanto de borracha como de agricultura) e com bens de consumo mínimos (sal, sabão, tecido) - ele estava por volta de 400 quilos por unidade doméstica em 1983. A ordenada correspondente dava o volume de farinha mínimo necessário para alimentar uma unidade doméstica (ele correspondia a cerca de 1.200 quilos anuais se não me falha a memória). Ora, esse plano de produção mínimo representava um custo em trabalho direto e indireto por grupo doméstico. Por outro lado, considerei o tempo de trabalho potencial disponível 
(que depende do estágio de desenvolvimento do grupo doméstico). A diferença entre o trabalho potencial e o trabalho necessário é o tempo disponivel para o grupo doméstico - e que podia ser utilizado seja maximizando a produção de borracha, seja maximizando a produção agrícola, seja maximizando a caça e a coleta - ou seja, o "tempo de coleta" que não é produtivo (bens agrícolas) nem "extrativo" (borracha). Ora, o diagrama tinha uma implicação teórica, mas também empírico-etnográfica, porque mostrei com quadros e tabelas que havia familias em todas as situações intermediárias entre os casos extremos acima - casos estes correspondentes aos vértices de um triângulo de "possibilidades de produção".

Todo esse raciocínio era entendido da seguinte forma. A organização dos seringais através do barracão travava uma disputa com a organização das unidades domésticas. Nessa disputa, o barracão visava maximizar a produção de borracha, e as casas de seringueiros visavam metas de boa vida dentro dos limites impostos pela organização do seringal. Ora, essa relação não era uma relação entre capitalista e operário, porque - argumentei - faltava do lado capitalista a subordinação formal e real do trabalhador ao capital; trocando em miúdos, falta a redução dos trabalhadores a operários assalariados, e da extração silvestre em plantações domesticadas. Faltava, finalmente, a expropriação formal e real dos trabalhadores. Expressei essa situação caracterizando o caráter da economia dos seringueiros como uma economia camponesa.

E a implicação dessa análise era que o conflito no interior dos seringais - observado por mim etnograficamente - tinha o caráter de um conflito de camponeses contra uma classe de proprietários-rentistas e capitalistas usurários-comerciais. A implicação também era de que a meta dos seringueiroscamponeses era a de ser tornarem camponeses florestais sem o patrão. Foi essa meta que caracterizei, inspirado nas ideias de John Roemer, como uma revolução.

Mas, Roemer advertia que uma revolução tem um custo: para sair do jogo da exploração (aqui, rentista e usurário-comercial) expulsando os exploradores sem perda, é preciso substituir aquilo que os exploradores faziam. Era preciso substituir o fornecimento de mercadorias e a venda de borracha - e essa foi a função da "cooperativa", bem como a implementação de normas de uso das estradas - e essa foi a função dos "fiscais" da Associação. Mas... faltava ainda uma peça fundamental, que era manter o sistema de preços administrados e de mercado cativo - que dependia do sistema político nacional no qual a antiga 
classe de patrões-latifundários da Amazônia tinha tido uma voz. Os seringueiros apenas começavam a ser ouvidos nesse plano. Mas sua voz não se expressou em política econômica - e na mesma década em que as Reservas Extrativistas começaram a ser criadas, isto é, na década de 1990, efetivou-se o desmonte do mercado protegido para a "borracha nacional". Os seringueiros tinham ganho uma batalha pelos territórios de seringais - mas tinham ganho florestas que de um ano para o outro tinham perdido seu valor enquanto capital natural do ponto de vista do mercado extrativo. E as promessas de um valor da floresta em pé do ponto de vista do "mercado para a biodiversidade" estavam longe de se transformarem em realidade...]

\section{REFERÊNCIAS}

ALLEGRETTI, Mary H. Os seringueiros (estudo de caso em um seringal nativo do Acre). Dissertação (Mestrado em Antropologia) - Universidade de Brasília, Brasília, 1979 .

"Submissão e revolta nos seringais: uma análise da dimensão simbólica da dominação" [S.1.], 1989. Manuscrito.

. Extractive reserves: an alternative for reconciling development and environmental conservation in Amazonia. In: ANDERSON, A. (Ed.). Alternatives to deforestation: steps toward sustainable use of the Amazon rain forest. New York: Columbia University Press, 1990. p. 252-264.

ALMEIDA, Mauro W. B. "Redescobrindo a Família Rural Brasileira". Revista Brasileira de Ciências Sociais vol.1, n 1 julho. ANPOCS - São Paulo. pp. 66-83, 1986.

- Dilemas da Razão Pratica: Simbolismo, Tecnologia e Ecologia na Floresta Amazônica. Anuário Antropológico, Brasília, v. 86, p. 213-226, 1988.

. As colocações como forma social, sistema tecnológico e unidade de recursos naturais. Terra Indigena, Araraquara, v. 7, n. 54, p. 29-39, 1990.

. Problemas no uso da vida silvestre por seringueiros. In: CONGRESO INTERNACIONAL SOBRE MANEJO DE FAUNA SILVESTRE EN LA AMAZONIA, 1992, [S. 1.]. Resúmenes... 1992. Disponível em: <www.geoplan.ufl.edu/congreso4/ congabs1.html - 1>. Acesso em: 5 maio 2012.

Rubber tappers of the upper Jurua river: the making of a forest peasantry. Tese (Doutorado Social Antropology) - University of Cambridge, 1993. 
0 Estatuto da Terra e As Reservas Extrativistas. Reforma Agrária, v. 25, n. 1, p. 153-168, 1995.

. Direitos à floresta e ambientalismo: os seringueiros e suas lutas. Revista Brasileira de Ciências Sociais, São Paulo, v. 19, n. 55, p. 34-53, 2004.

ALMEIDA, Mauro W. B.; PANTOJA FRANCO, Mariana C. Justiça local nas reservas extrativistas. Raízes, Campina Grande, v. 23, n. 1-2, p. 27-41, 2005.

AQUINO, Terri Vale de. De seringueiro caboclo a peão acreano. 1977. Dissertação (Mestrado em Antropologia) - Universidade de Brasília, Brasília.

BAKX, Keith. Peasant formation and capitalist development: the case of Acre, south-west Amazonia. 1986. Tese (Doutorado em Filosofia) - University of Liverpool, United Kingdom.

. From proletarian to peasant: rural transformation in the State of Acre, 1870-1986. Journal of Development Studies, United Kingdom, v. 24, n. 2, p. 14160, 1988.

BODMER, Richard E., FANG, Tula G. \& IBANEZ, Luis M. 1988. Primates and ungulates: a comparison of susceptibility to hunting. Primate Conservation 9, p.7980, 1988

Ungulate management and conservation in the peruvian Amazon. Biological Conservation 45, p. 303-10, 1988.

BOEKE, Julius Herman. Economics and economic policy of dual societies. New York: Institute of Pacific Relations, 1953.

BROWN, Keith S. Parecer ecológico... Relatório a pedido da Procuradoria Geral da Republica. Manuscrito, 1991.

BUNKER, Stephen G. Underdeveloping the Amazon: extraction, unequal exchange, and the failure of the modern state. Urbana and Chicago: The University of Illinois Press, 1985.

CARNEIRO DA CUNHA, M. Manuela; ALMEIDA, Mauro W. B. A enciclopédia da floresta. São Paulo: Companhia das Letras, 2002.

CHAYANOV, Aleksandr. V. On the theory of peasant economy. Wisconsin: The University of Wisconsin Press, 1986.

DASGUPTA, P. S.; HEAL, G. M. Economic theory and exhaustible resources. Cambridge: Cambridge University Press, 1979. 
DESCOLA, Philippe. La nature domestique. Paris: Maison des Sciences de L'Homme, 1983.

DIAS, Carla de Jesus; ALMEIDA, Mauro W. B. A floresta como mercado: caça e conflitos na Reserva Extrativista do Alto Juruá - Acre. Boletim Rede Amazônica, Rio de Janeiro, v. 3, n. 1, p. 9-27, 2004.

DUARTE, Elio G. Conflitos pela terra no Acre. Rio Branco: Casa da Amazônia, 1987.

ELLIS, Frank. Peasant economics: farm households and agrarian development. Cambridge, Cambridge University Press, 1988.

FURTAD0, Celso. Formação econômica do Brasil. São Paulo: Companhia das Letras, 1959.

HECHT, Susanna \& COCKBURN, Alexander. The fate of the forest: developers, destroyers and defenders of the Amazon. New York: Verso, 1991.

HECHT, Susanna \& SCHWARTZMAN, Stephen. The good, the bad and the ugly: amazonian extraction, colonist agriculture, and livestock in comparative perspective. Manuscrito, 1988.

HECHT, Susanna, NOORGARD, Richard, \& POSSI0, Giorgio. The economics of cattle ranching in eastern Amazonia. Interciencia, Vol. 13, No. 5, Caracas, 1988.

HECHT, Susanna. Environment, development and politics: capital accumulation and the livestock sector in eastern Amazonia. World Development, vol.13, n.6, p. 663-84, 1985.

IBGE. IX Recenseamento geral do Brasil - 1980. Censo demográfico - Mão de obra. Acre. Rio de Janeiro, IBGE, 1983a. v. 1, tomo 5, n. 3.

. IX Recenseamento geral do Brasil - 1980. Censo agropecuário. Acre. Rio de Janeiro, IBGE, 1983b. v. 2, tomo 3, n. 3. IBGE, 2006a.

Censo agropecuário - 2006: resultados preliminares. Rio de Janeiro: .Censo agropecuário - 2006: agricultura familiar: primeiros resultados: Brasil, grandes regiões e unidades da federação. Rio de Janeiro: IBGE, 2006b. MARTINS, José de Souza. O poder do atraso. São Paulo: Hucitec, 1994. 
PANTOJA FRANCO, Mariana C. et al. Botar roçados. In: CARNEIRO DA CUNHA, M. Manuela; ALMEIDA, Mauro W. B. A enciclopédia da floresta. São Paulo: Companhia das Letras, 2002.

POSTIGO, Augusto de Arruda. A terra vista do alto: usos e percepções acerca do espaço entre os moradores ro rio Bagé, Acre. 2010. Tese (Doutorado em Antropologia) - Universidade Estadual de Campinas.

RAMOS, Rossano Marchetti. Estratégia de caça e uso de fauna na reserva extrativista do Alto Juruá-Ac. 2005. Dissertação (Mestrado em Ciência Ambiental) - Universidade de São Paulo.

SMITH, Maira; VIDALENC, Daniela. A percepção de vegetais pela população local no alto Rio Tejo. São Paulo, 1997. Relatório de Iniciação Científica para a FAPESP. TAUSSIG, Michael.Xamanismo, colonialismo e o homem selvagem. Petrópolis: Paz e Terra, 1993.

TEIXEIRA, Carlos. O aviamento e o barracão na sociedade do seringal. 1980. Dissertação (Mestrado em Sociologia) - Universidade de São Paulo. São Paulo. 


\section{AneXo I. Tabelas}

Tabela 1 - Ocupação da mão-de-obra no Acre, 1980

\begin{tabular}{|c|c|c|c|c|c|c|}
\hline & Total & Homens & Mulheres & Total & Homens & Mulheres \\
\hline Total & 93065 & 76937 & 16128 & $100 \%$ & $100 \%$ & $100 \%$ \\
\hline Urbana Total & 43320 & 30291 & 13029 & $47 \%$ & $39 \%$ & $81 \%$ \\
\hline Rural Total & 49745 & 46646 & 3099 & $53 \%$ & $61 \%$ & $19 \%$ \\
\hline $\begin{array}{l}\text { Agric., Silv. e Pecuária (\% } \\
\text { do total) }\end{array}$ & 20749 & 19488 & 1261 & $22 \%$ & $25 \%$ & $8 \%$ \\
\hline $\begin{array}{l}\text { Extração Vegetal (\% do } \\
\text { total) }\end{array}$ & 23110 & 22885 & 225 & $25 \%$ & $30 \%$ & $1 \%$ \\
\hline $\begin{array}{l}\text { Extração Vegetal } \\
\text { (Borracha) (\% do total) }\end{array}$ & 22955 & 22730 & 225 & $25 \%$ & $30 \%$ & $1 \%$ \\
\hline Rural Total & 49745 & 46646 & 3099 & $100 \%$ & $100 \%$ & $100 \%$ \\
\hline $\begin{array}{l}\text { Agric., Silv. e Pecuária (\% } \\
\text { do rural) }\end{array}$ & 20749 & 19488 & 1261 & $42 \%$ & $42 \%$ & $41 \%$ \\
\hline $\begin{array}{l}\text { Extração Vegetal (\% do } \\
\text { rural) }\end{array}$ & 23110 & 22885 & 225 & $46 \%$ & $49 \%$ & $7 \%$ \\
\hline $\begin{array}{l}\text { Extração Vegetal } \\
\text { (Borracha) (\% do rural) }\end{array}$ & 22955 & 22730 & 225 & $46 \%$ & $49 \%$ & $7 \%$ \\
\hline $\begin{array}{l}\text { Extração vegetal } \\
\text { (Borracha) urbana }\end{array}$ & 858 & 845 & 13 & $2 \%$ & $2 \%$ & $0 \%$ \\
\hline $\begin{array}{l}\text { Extração vegetal } \\
\text { (Borracha) urbana e rural }\end{array}$ & 23813 & 23575 & 238 & $26 \%$ & $31 \%$ & $1 \%$ \\
\hline
\end{tabular}

Fonte: IBGE (1983a, p. 26).

Tabela 2 - Valor da produção rural - Acre 1980

\begin{tabular}{|l|c|c|}
\hline Valor total $(\mathrm{R} \$)$ & 2395274 & $100 \%$ \\
\hline Lavouras & 1210955 & $51 \%$ \\
\hline Horticultura e Floricultura & 11535 & $0 \%$ \\
\hline Silvicultura & 0 & $0 \%$ \\
\hline Extração Vegetal & 1172782 & $49 \%$ \\
\hline
\end{tabular}

Fonte: (IBGE, 1983b, p. 55) 
Tabela 3 - Área em uso por atividade - 1970 a 2006

\begin{tabular}{|l|c|c|c|c|c|c|}
\hline Censos & 1970 & 1975 & $\mathbf{1 9 8 0}$ & 1985 & 1995 & 2006 \\
\hline Área do Estado & 100 & 100 & $\mathbf{1 0 0}$ & 100 & 100 & 100 \\
\hline Área em Uso (ha) & $27 \%$ & $28 \%$ & $\mathbf{3 7 \%}$ & $34 \%$ & $21 \%$ & $25 \%$ \\
\hline Lavouras & $0 \%$ & $0 \%$ & $\mathbf{1 \%}$ & $0 \%$ & $0 \%$ & $1 \%$ \\
\hline Pastagens & $0 \%$ & $1 \%$ & $\mathbf{2 \%}$ & $2 \%$ & $4 \%$ & $7 \%$ \\
\hline Matas e Florestas & $26 \%$ & $27 \%$ & $\mathbf{3 3 \%}$ & $30 \%$ & $15 \%$ & $17 \%$ \\
\hline
\end{tabular}

Fonte: IBGE (2006a)

Tabela 4 - Estabelecimentos segundo atividade. Acre, 1980

\begin{tabular}{|l|c|c|c|c|c|c|}
\hline & \multicolumn{2}{|c|}{ Totais } & \multicolumn{2}{c|}{ Totais não-proprietário } & \multicolumn{2}{c|}{ Proprietário } \\
\hline & Est. & Área (ha) & Est. & Area (ha) & Est. & Area (ha) \\
\hline Totais Atividades Rurais & 27371 & 5679532 & 19411 & 3575196 & 7960 & 2104336 \\
\hline Agr. Agrop. & 10919 & 989822 & 5909 & 627958 & 5010 & 361864 \\
\hline Extr. Veg. & 13360 & 2916782 & 12213 & 2723830 & 1147 & 192952 \\
\hline
\end{tabular}

Fonte: IBGE (1983b, p. 8). 


\section{Anexo 2. Croquis De SERINGAL}

Mapa 1 - Localização geral

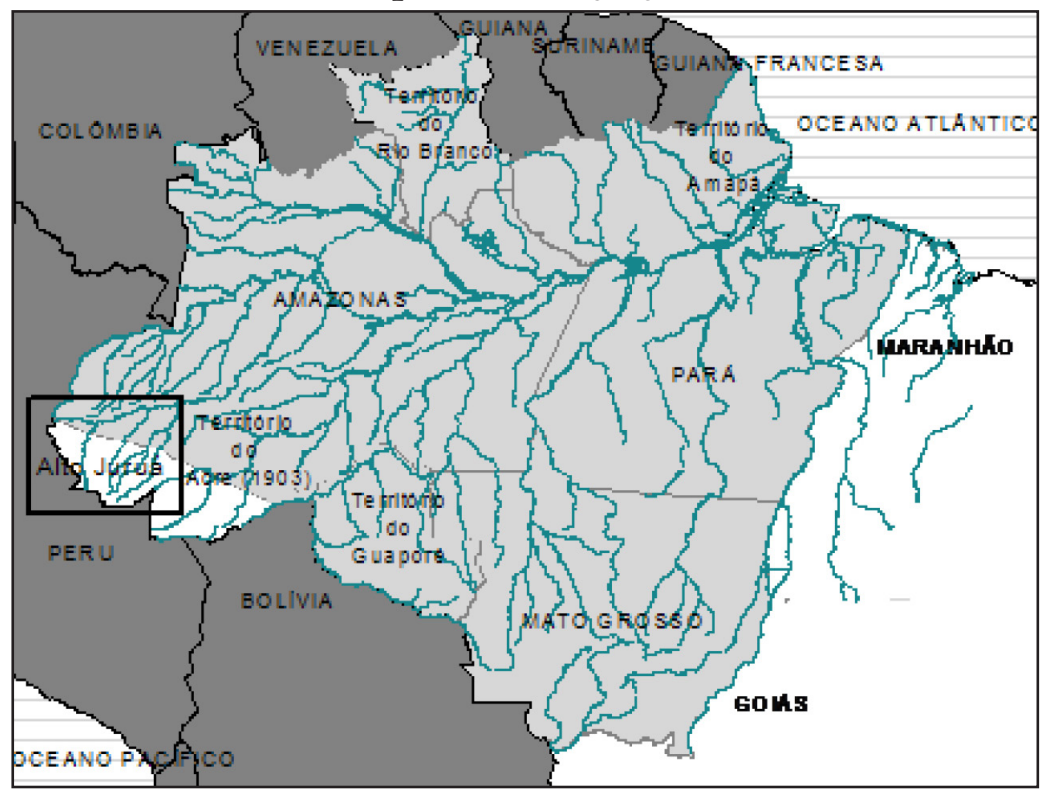

Fonte: Autor. Conferir nota 17

Mapa 2 - Acre e atual reserva extrativista do Alto Juruá

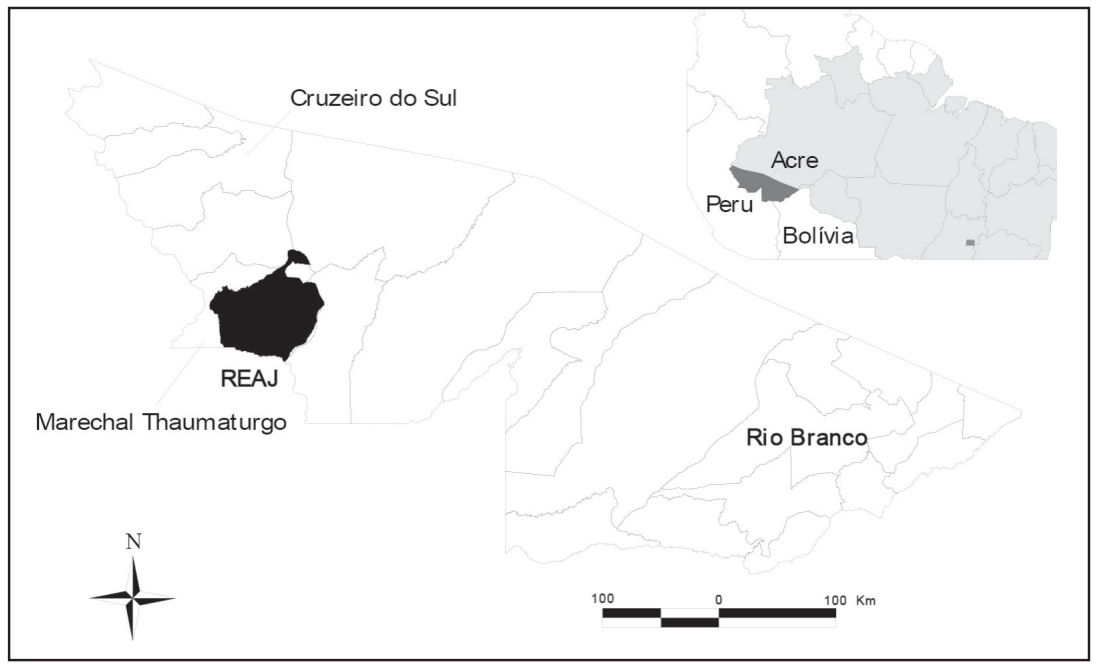

Fonte: Autor. Conferir nota 17 
Mapa 3 - Seringais da bacia do rio Tejo

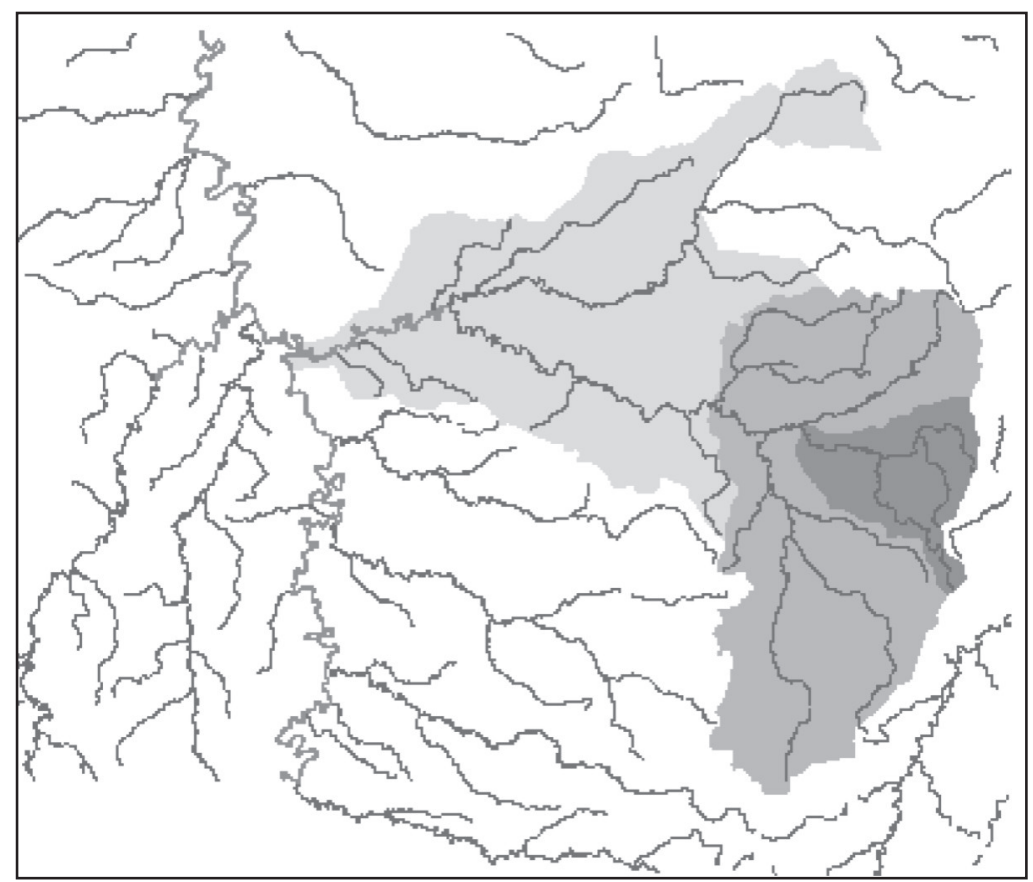

Cinza claro: bacia do rio Tejo (Sede geral: Foz do Tejo)

Cinza médio: Seringal Restauração (sede: Restauração)

Cinza escuro: Seringal Riozinho (depósito: colocação "Depósito do Riozinho").

Fonte: Autor. Conferir nota 17 


\section{Mapa 4 - Riozinho}

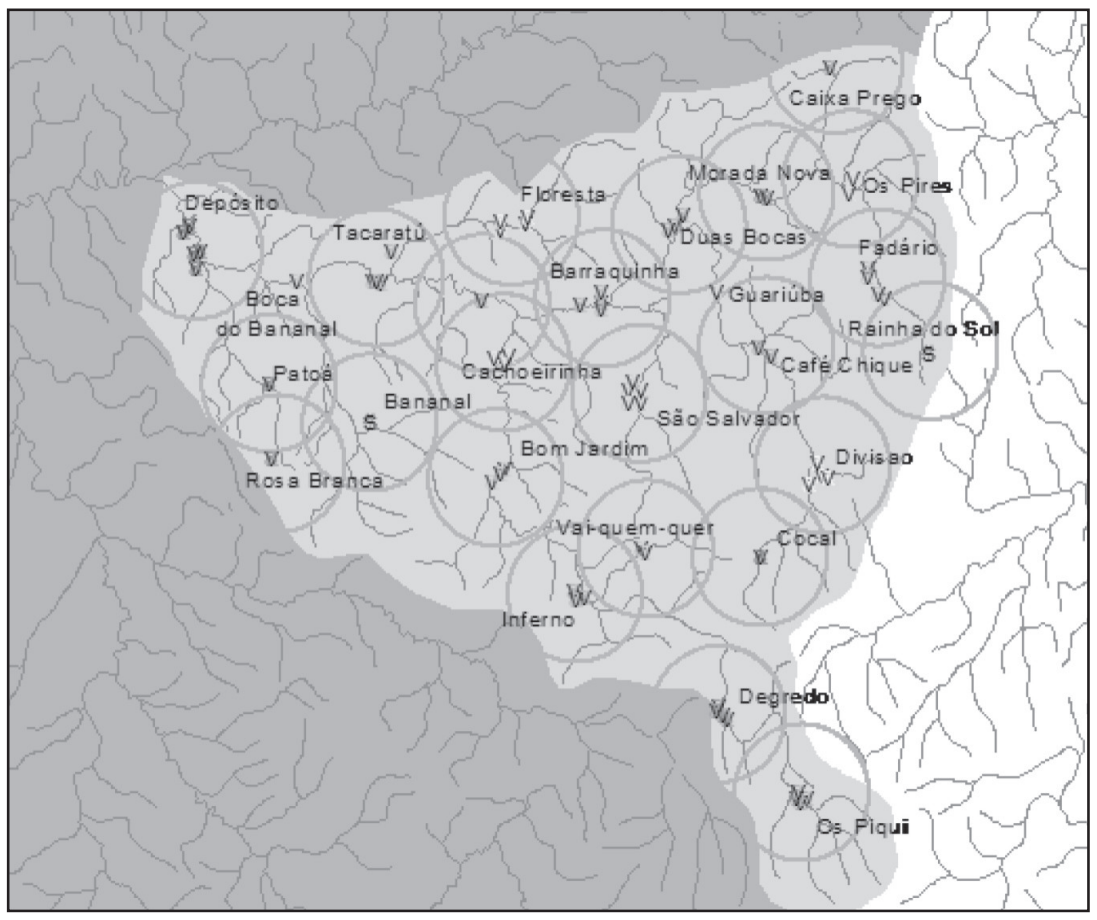

Os símbolos representam as clareiras e campos onde se localizam as casas de uma colocação. Os círculos indicam uma área aproximada onde se localizam as estradas e áreas de caçada de cada colocação.

Fonte: Autor. Conferir nota 17 